\title{
A Brief Survey of Regionalization Modeling; A Bonus from Gauged to Ungauged Basins
}

ISSN: 2639-0574

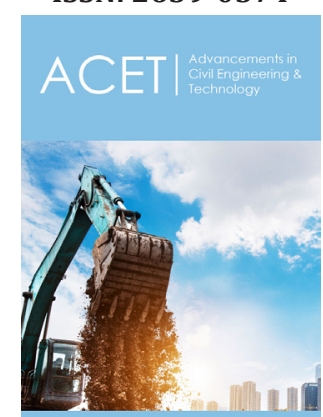

${ }^{* 1}$ Corresponding author: Mehdi Sheikh Goodarzi, Department of Environmental Science and Engineering, Tehran, Iran

Submission: 海 July 13, 2019

Published: 㘹July 29, 2019

Volume 3 - Issue 4

How to cite this article: Mehdi Sheikh G, Shabnam N. A Brief Survey of Regionalization Modeling; A Bonus from Gauged to Ungauged Basins. Adv Civil Eng Tech. 3(4). ACET.000566.2019.

DOI: 10.31031/ACET.2019.03.000566

Copyright@ Mehdi Sheikh Goodarzi, This article is distributed under the terms of the Creative Commons Attribution 4.0 International License, which permits unrestricted use and redistribution provided that the original author and source are credited.

\author{
Mehdi Sheikh Goodarzi ${ }^{1 *}$ and Shabnam Navardi ${ }^{2}$ \\ ${ }^{1}$ Department of Environmental Science and Engineering, Tehran, Iran \\ ${ }^{2}$ Department of Environmental Engineering, Iran
}

\section{Introduction}

Runoff-rainfall models (r-r) have been widely used to manage water resources during past decades. One of the most important upfront hydrological issues, certainly in r-r prediction, is adopting the best calibration method [1]. Regarding the importance of calibration procedure in hydrological modeling, various types of methods and approaches have been practiced optimizing parameter values from manual and trial-error-based style to entirely automated, heuristic and sophisticated approaches. Automatic calibration approaches usually take advantage of modern search processes and algorithms to fit residual errors among observed and simulated data (using objective functions) to optimize parameter values [2]. In terms of hydrological modeling, particularly distributed models, changes in spatial characteristics of watersheds and resulting processes, are considered explicitly [3]. These types of models are fundamentally designed to bear various sorts of flow information and watershed attributes to model streamflow accurately and timely (i.e. Big Data Machine Learning [4]).

These models are dispersedly used in flood and discharge prediction of inoperative sites concerning their long runtime and high volume of input data [3,5]. In contrast, there is a particular group of models so called "conceptual models" which conceive hydrological process at all and retrieve hydrological parameters through calibration process. These sorts of models are mainly utilized in ungauged watersheds whose temporal climatological records are dominantly unqualified [6]. Conceptual methods are initially founded on the black-box logic [7].

All of the methods that enable researchers to transform hydrological information (from donor watershed to recipient target), are considered as regionalization analysis series. Regionalization is a broadly appealed process parallel to calibration, with the advantage of limitless application throughout watersheds [8]. Due to the process, regionalization can simply be implemented by establishing an empirical relationship between dependent (flow components or optimized parameters of hydrological models) and independent variables (ecological factors). In term of this, general accuracy of regionalization analysis is mainly a function of input data and methods used (throughout the process). Regionalization is generally planned to apply in ungauged watersheds via two main approaches including flow-based and parameter-based $[9,10]$. Flow-based regionalization bears flow components such as sediment discharge fluctuation curve, maximum observed flood discharge, prolapsed and peak times of flood durations, flood duration curve parameters, base, peak and mean annual flows. On the other hand parameter-based approach considers slope, watershed area, percentage of landuse and landcover, elevation, length of main river, drainage density, topographic index, soil and bedrock classes, electrical conductivity and porosity, solar extra radiation, temperature and precipitation, and landscape ecological metrics $[8,9,11,12]$.

Having reviewed the literature, featured an above average performance for structural similarity [13-15] and Parametric Regression [16-18], while Averaging [19,20] and Spatial 
Proximity [21,22] have shown an acceptable result. The most important issue about regional calibration is the necessity of scenario planning. Accordingly, regional calibration method was effectively employed through the following studies [23-29]. Additionally, watershed numbers (as an iteration unit) should be deeply pondered. In general, modeling performance is getting promoted in line with the increasing number of watersheds. Albeit, inaccurate gauging statistics lead modeling efficiency to downtrend [30].

Furthermore, model type and number of applicable parameters can also be taken into consideration. Following the Parajka et al. [30] and He et al. [8], modeling performance was reversely correlated by the number of parameters. Similarly, such a phenomenon is expectable in models with a large number of parameters (usually more than 15 parameters). Additionally, Synergy effects of number of parameters, watershed area and watershed multiplicity, climate and regionalization method are impressive issues that should be strategically involved in the modeling process in order to make appropriate decisions and applied achievements. For instance, the similarity and spatial proximity methods have shown a higher performance in comparison with regionalization methods (in particular with the Averaging) in the second level tropical watersheds [30].

\section{References}

1. Sheikh Goodarzi M (2013) General review of ecosystem based hydrological modeling technics. PhD Seminar, Department of Environment, University of Tehran, Iran, p. 59.

2. Wang YC, Yu P, Yang T (2010) Comparison of genetic algorithms and shuffled complex evolution approach for calibrating distributed rainfallrunoff model. Journal of Hydrological Process 24(8): 1015-1026.

3. Reed S, Koren V, Smith M, Zhang Z, Moreda F, et al. (2004) Overall distributed model inter-comparison project results. Journal of Hydrology 298(1-4): 27-60.

4. Petty TR, Dhingra P (2018) Streamflow hydrology estimate using machine learning (SHEM). Journal of the American Water Resources Association (JAWRA) 54(1): 55-68.

5. Khakbaz B, Imam B, Hsu K, Sorooshian S (2012) From lumped to distributed via semi-distributed: Calibration strategies for semidistributed hydrologic models. Journal of Hydrology 418-419: 61-77.

6. Ekenberg M (2016) Using a lumped conceptual hydrological model for five different catchments in Sweden. Master's thesis Physical Geography and Quaternary Geology, University of Stockholm, Sweden.

7. Bormann B, Breuer L, Giertz S, Huisman JA, Viney NR (2009) Uncertainties in environmental modelling and consequences for policy making part of the series NATO Science for Peace and Security Series C: Environmental Security. Chapter: Spatially explicit versus lumped models in catchment hydrology-experiences from two case studies, pp. 3-26.

8. He Y, Bardossy A, Zehe E (2011) A review of regionalization for continuous streamflow simulation. Hydrol Earth Syst Sci 15: 3539-3553.

9. Vandewiele GL, Xu CY, Huybrechts W (1991) Regionalization of physically based water balance models in Belgium application to ungauged catcbiients. Water Resources Management 5(3-4): 199-208.
10. Hundecha Hirpa Y (2005) Regionalization of parameters of a conceptual rainfall-runoff model. PhD Thesis, Institut für Wasserbau der Universität Stuttgart, Stuttgart, Germany, p. 129.

11. Yokoo Y, Kazama S, Sawamoto M, Nishimura H (2001) Regionalization of lumped water balance model parameters based on multiple regression. J Hydrol 246(1-4): 209-222.

12. Hundecha Y, Bardossy A (2004) Modeling of the effect of land use changes on the runoff generation of a river basin through parameter regionalization of a watershed model. J Hydrol 292(1-4): 281-295.

13. Beck HE, Van Dijk AIJM, De Roo A, Miralles DG, McVicar TR, et al. (2016) Global-scale regionalization of hydrologic model parameters. Water Resour Res 52: 3599-3622.

14. Bulygina N, McIntyre N, Wheater H (2009) Conditioning rainfall runoff model parameters for ungauged catchments and land management impacts analysis. Hydrol Earth Syst Sci 13: 893-904.

15. Li H, Zhang Y, Chiew FHS, Xu S (2009) Predicting runoff in ungauged catchments by using Xinanjiang model with MODIS leaf area index. J Hydrol 370(1-4): 155-162.

16. Young AR (2006) Stream flow simulation within UK ungauged catchments using a daily rainfall-runoff model. J Hydrol 320(1-2): 155172.

17. Boughton W, Chiew $F$ (2007) Estimating runoff in ungauged catchments from rainfall, PET and the AWBM model. Environm Modell Softw 22(4): 476-487.

18. Kim D, Jung I, Chun JA (2016) A comparison between parameter regionalization and model calibration with flow duration curves for prediction in ungauged catchments. Hydrol Earth Syst Sci Discuss.

19. Zvolensky M, Kohnova S, Hlavcova K, Szolgay J, Parajka J (2007) To the application of spatial interpolation methods for estimation of rainfallrunoff model parameters in ungauged catchments. Meteorolog J 10: $145-152$.

20. Goswami M, O Connor KM (2007) Comparative assessment of six automatic optimization techniques for calibration of a conceptual rainfall-runoff model. Hydrological Sciences Journal 52(3): 432-449.

21. Caballero LA, Easton ZM, Richards BK, Steenhuis TS (2013) Evaluating the bio-hydrological impact of a cloud forest in Central America using a semi-distributed water balance model. J Hydrol Hydromech 61(1): 9-20.

22. Petheram C, Potter N, Vaze J, Chiew F, Zhang L (2011) Towards better understanding of changes in rainfall runoff relationships during the recent drought in southeastern Australia. 19 ${ }^{\text {th }}$ International Congress on Modelling and Simulation, Perth, Australia.

23. Parajka J, Bloschl G, Merz R (2007) Regional calibration of catchment models: Potential for ungauged catchments. Water Resour Res 43: 1-6.

24. Parajka J, Merz R, Bloschl G (2005) A comparison of regionalization methods for catchment model parameters. Hydrol Earth Syst Sci 9: 157171.

25. Hundecha Y, Ouarda TBMJ, Bardossy A (2008) Regional estimation of parameters of a rainfall-runoff model at ungauged watersheds using the "spatial" structures of the parameters within a canonical physiographicclimatic space. Water Resour Res 44: W01427.

26. Reichl JPC, Western AW, McIntyre N, Chiew FHS (2009) Optimization of a similarity measure for estimating ungauged streamflow. Water Resour Res 45: W10423.

27. Samuel J, Coulibaly P, Metcalfe R (2011) Estimation of continuous streamflow in Ontario ungauged basins: comparison of regionalization methods. J Hydrol Eng 16: 447-459. 
28. Kim U, Kaluarachchi J (2008) Application of parameter estimation and regionalization methodologies to ungauged basins of the Upper Blue Nile River Basin, Ethiopia. J Hydrol 362(1-2): 39-56.

29. Oudin L, Andreassian V, Perrin C, Michel C, Le Moine N (2008) Spatial proximity, physical similarity, regression and ungagged catchments: A comparison of regionalization approaches based on 913 French catchments. Water Resour Res 44: 1-15.
30. Parajka J, Viglione A, Rogger M, Salinas JL, Sivapalan M, et al. (2013) Comparative assessment of predictions in ungauged basins-Part 1: Runoff-hydrograph studies. Journal of Hydrol Earth Syst Sci 17: 17831795.

For possible submissions Click below: 